\title{
Introduction: welcome to the world of intellectual capital
}

John Dumay, Christian Nielsen and Morten Lund

Welcome to the world of intellectual capital (IC). It is a world where value is created from something we cannot touch but can identify and measure, manage and report. Ours is a world of ambiguity where value hides inside a company. Therefore, managers and academics need to carefully and intricately work on making IC visible. Through research on understanding IC and how it works, we make it less ambiguous and allow managers to incorporate it into practice. In a world where value creation mainly stems from intangible assets and where workflows and processes are ever more digital, understanding how IC creates value is critical.

IC research has a long and varied history based on the work of practitioners, journalists and academics such as Sveiby (1989), Kaplan and Norton (1992), Stewart (1997), Edvinsson (1997) and Guthrie and Petty (2000). These people have made significant contributions to the foundations of IC research, and most still do today. However, the challenge is how we continue to build on their contribution to understanding IC in a world where conservative accounting practices prevent the balance sheet from representing an enterprise's future value (Barker, 2015). In the following chapters, we take up the challenge by building on past IC research methodologies and introducing new opportunities to build understandings of IC that reach the future.

In academia, researchers are always under pressure to meet specific criteria from the journals and their editors. Sometimes these pressures tend to conform to methodological contributions and constrain them. Our objective with the Research Handbook on Intellectual Capital and Business is to provide a haven where methodological contributions to IC research can flourish. Our ambition is to publish a handbook that guides inexperienced IC researchers in their search for methodologies to help them make novel and timely contributions. For more established researchers, the Handbook offers an assembly of refreshing and straight forward contributions stripped of the traditional journal format constraints.

The chapters are written by leading IC academics and practitioners. The authors represented here all have an IC research specialisation or have developed novel approaches to IC research. By sharing their IC research 
knowledge with you, we hope to open up further developments in traditional IC research methodologies and inspire novel research to take its form in the future. Thus, we organise the book chapters within four parts, starting with traditional research methodologies and then expanding into novel IC research approaches.

\section{PART I: CONTENT ANALYSIS}

While being a traditional IC research methodology, content analysis has been the subject of critique and criticism (Dumay and Cai, 2014, 2015). The critique and criticism centres upon an abundance of research analysing annual reports for IC content in different industries and jurisdictions (Dumay, 2014). Alternatively, supporters identify content analysis as well established and not overly time-consuming; there is easy access to data; it is low-cost research; and still capable of developing insights not possible with other research methods (Guthrie, 2014). Thus, content analysis is not quite a dead end yet, and continues to transform and remain a legitimate IC research methodology (Goebel, 2015a, 2015b).

The chapters included in the content analysis part provide critique as well as examples of novel approaches. Continually reimagining content analysis as a methodology for IC research opens the door to new and exciting discoveries. Thus, we present chapters offering critique (Bini and Giunta, Chapter 1; Goebel, Chapter 2; Abhayawansa et al., Chapter 3) alongside chapters that offer novel approaches and new insights into conducting IC content analysis research (Hussinki et al., Chapter 4; Lai et al., Chapter 5; Rimmel and Cordazzo, Chapter 6; Simoni and Giunta, Chapter 7).

\section{PART II: VISUAL METHODOLOGIES}

A picture is worth a thousand words, says the old Chinese proverb and the ability to visualise intangibles might be worth thousands of dollars. IC research has more recently considered how visualising IC can help managers understand how their organisation creates and destroys value (Cuganesan and Dumay, 2009; Davison, 2014). However, visualising IC is challenging, and thus we need novel methodologies as there is no generic and widely known and accepted methodology for visualising IC. Thus, considering making the intangible visible is a challenge for IC researchers and practitioners, we include a chapter that offers an overview of research methodologies (Michalak, Chapter 8) and two chapters that help develop further research on this topic (Giuliani, Chapter 9; Low and Sharma, Chapter 10). 


\section{PART III: VALUE ADDED INTELLECTUAL COEFFICIENT (VAIC)}

The VAIC methodology is another widely critiqued and modified IC research methodology (Ståhle et al., 2011). Pulic's (2000) original methodology's simplicity is both its greatest strength and greatest weakness as most critiques seek to change and add extra variables (Nadeem et al., 2019). VAIC also suffers critique similar to content analysis because many papers investigate different industries or jurisdictions, thus offering infinite research possibilities. Thus, we include chapters that continue the developing discourse expanding the original VAIC methodology (Iazzolino and Laise, Chapter 11; Mooneeapen et al., Chapter 12; Nadeem and Zaman, Chapter 13).

\section{PART IV: NOVEL APPROACHES}

Novel approaches, searching critiques and solutions that business, professional and scholarly communities demand are the things that create new discoveries (Guthrie, 2014). Thus, the last section includes chapters that offer these novel approaches because IC research needs to expand beyond its boundaries (Dumay et al., 2018). The chapters in this last part deal with such novel approaches by examining IC research relating to social networks (Lombardi and Schimperna, Chapter 14), different research methodologies (Durst, Chapter 15; Nielsen and Lund, Chapter 16; Veltri, Chapter 17) and building on theory (Roos, Chapter 18). Thus, these final chapters demonstrate novel approaches that expand beyond IC's boundaries. We hope these and the other chapters in this book inspire you to undertake IC research that makes a difference and ushers in a brand-new world of IC knowledge.

\section{REFERENCES}

Barker, R. (2015). Conservatism, prudence and the IASB's conceptual framework. Accounting and Business Research, 45(4), 514-538. https://doi.org/10.1080/00014788.2015. 1031983.

Cuganesan, S., and Dumay, J. (2009). Reflecting on the production of intellectual capital visualisations. Accounting, Auditing and Accountability Journal, 22(8), 1161-1186. http:// www.emeraldinsight.com/10.1108/09513570910999274.

Davison, J. (2014). Visual rhetoric and the case of intellectual capital. Accounting, Organizations and Society, 39(1), 20-37. https://doi.org/http://dx.doi.org/10.1016/j. aos.2014.01.001.

Dumay, J. (2014). 15 years of the Journal of Intellectual Capital and counting: a manifesto for transformational IC research. Journal of Intellectual Capital, 15(1), 2-37. https://doi. org/10.1108/JIC-09-2013-0098. 


\section{$4 \quad$ Research handbook on intellectual capital and business}

Dumay, J., and Cai, L. (2014). A review and critique of content analysis as a methodology for inquiring into IC disclosure. Journal of Intellectual Capital, 15(2), 264-290. https://doi. org/10.1108/JIC-01-2014-0010.

Dumay, J., and Cai, L. (2015). Using content analysis as a research methodology for investigating intellectual capital disclosure: a critique. Journal of Intellectual Capital, 16(1), 121-155. https://doi.org/10.1108/JIC-04-2014-0043.

Dumay, J., Guthrie, J., and Rooney, J. (2018). The critical path of intellectual capital. In J. Guthrie, J. Dumay, F. Ricceri and C. Nielsen (eds), The Routledge Companion to Intellectual Capital: Frontiers of Research, Practice and Knowledge (pp. 21-39). London: Routledge.

Edvinsson, L. (1997). Developing intellectual capital at Skandia. Long Range Planning, 30(3), 366-373. http://www.sciencedirect.com/science/article/B6V6K-4B38653-6/2/4063fb36f12d aa98e33257f5049cc9ba.

Goebel, V. (2015a). Intellectual capital reporting in a mandatory management report: the case of Germany. Journal of Intellectual Capital, 16(4), 702-720. https://doi.org/ doi:10.1108/JIC-02-2015-0011.

Goebel, V. (2015b). Is the literature on content analysis of intellectual capital reporting heading towards a dead end? Journal of Intellectual Capital, 16(3), 681-699. https://doi. org/doi:10.1108/JIC-04-2014-0048.

Guthrie, J. (2014). In defence of disclosure studies and the use of content analysis: a research note. Journal of Intellectual Capital, 15(2), 291-292.

Guthrie, J., and Petty, R. (2000). Intellectual capital: Australian annual reporting practices. Journal of Intellectual Capital, 1(3), 241-251.

Kaplan, R.S., and Norton, D.P. (1992). The Balanced Scorecard - Measures that drive performance. Harvard Business Review, 70(1), 71-79. http://search.epnet.com/login.aspx?d irect $=$ true $\& \mathrm{db}=$ buh \&an $=9205181862$.

Nadeem, M., Dumay, J., and Massaro, M. (2019). If you can measure it, you can manage it: a case of intellectual capital. Australian Accounting Review, 29(2), 395-407. https://doi. org/10.1111/auar.12227.

Pulic, A. (2000). VAIC ${ }^{\mathrm{TM}}-$ an accounting tool for IC management. International Journal of Technology Management, 20(5/6/7/8), 702-714.

Ståhle, P., Ståhle, S., and Aho, S. (2011). Value added intellectual coefficient (VAIC): a critical analysis. Journal of Intellectual Capital, 12(4), 531-551. https://doi.org/DOI: $10.1108 / 14691931111181715$.

Stewart, T.A. (1997). Intellectual Capital: The New Wealth of Organisations. New York: Doubleday-Currency.

Sveiby, K.E. (1989). The Invisible Balance Sheet: Key Indicators for Accounting, Control and Valuation of Know-How Companies (translation). The Konrad Group. 